\title{
Chapter 10 \\ Global and National Food Safety \\ and Quality Standards: Implications \\ and Impacts for Farmers in Thailand \\ and India
}

\author{
Sarah Holzapfel and Aimée Hampel-Milagrosa
}

\section{Introduction}

In the last three decades, a transformation of the agricultural sector in the developing countries has taken place. The relative importance of staple crops and traditional export commodities (coffee, cacao, tea, sugar, spices and nuts) in agricultural trade and production has declined, and a shift towards high-value products can be observed (Humphrey \& Memedovic, 2006; Reardon \& Timmer, 2007; World Bank, 2008). In the developing countries, rapid economic growth, urbanization and globalization have induced changes in consumer diets away from staple foods towards an increased consumption of high-value products (Gulati, Minot \& Bora, 2007; Pingali, 2007; World Bank, 2008). As a result, the domestic market for high-value products is one of the fastest growing agricultural markets in many developing economies, expanding by $6-7 \%$ a year (World Bank, 2008). At the same time, the demand for speciality products and for a year-round supply of highly perishable fruits and vegetables has increased in industrialized countries, creating new exporting opportunities for many developing economies (World Bank, 2008).

However, in recent years, meeting the market requirements in high-value supply chains has become more challenging (Gulati et al., 2007). In particular, high-value export and domestic supply chains in developing countries are increasingly governed by a plethora of public and private food safety and quality standards (Balsevich et al., 2003; Henson \& Reardon, 2005). Developed countries' public standards have long been criticized for acting as non-tariff barriers to trade for exports from developing countries (Henson \& Caswell, 1999; Henson \& Loader, 2001; Otsuki, Wilson

\footnotetext{
S. Holzapfel (殴

Office of International Relations and Sustainable Development, Department for Mayoral and City Council's Affairs, Dortmund, Germany

e-mail: Sarah.Holzapfel@gmx.net
}

A. Hampel-Milagrosa

Asian Development Bank, Mandaluyong, Philippines

(C) The Editor(s) (if applicable) and The Author(s) 2020

A. Negi et al. (eds.), Sustainability Standards and Global Governance,

https://doi.org/10.1007/978-981-15-3473-7_10 
\& Sewadeh, 2001). Private standards, introduced and required by supermarkets, however, often exceed the requirements of public standards and, although voluntary, become mandatory to access high-value markets worldwide (Berdegué, Balsevich, Flores \& Reardon, 2005; Dolan \& Humphrey, 2000; Elizabeth \& Reardon, 2000; Jaffee et al., 2005). The pre-farmgate standard GlobalGAP ${ }^{1}$ is the most widely known private standard for good agricultural practices (GAPs). It was developed by a group of European retailers in 1997 with the aim of harmonizing retailers' existing standards and evolved to be a requirement of major retailers worldwide. The main focus of the standard is on food safety, but it also covers aspects of environmental protection, workers' health, safety and welfare, and traceability (GLOBAL GAP, 2012).

There is widespread concern among development practitioners and academics that small-scale farmers will lose access to high-value markets because of their inability to meet stringent private standards, such as GlobalGAP (Graffham, Cooper, Wainwright \& MacGregor, 2007; Humphrey \& Memedovic, 2006; Jaffee, Henson \& Rios, 2011). First, adopting private standards usually entails high compliance and certification costs that disadvantage smallholders. Second, small-scale farmers often lack the technical ability to adapt their farming practices to the requirements of standards (Jaffee et al., 2011; Narrod et al., 2009). Yet, others argue that the challenge can also be turned into an opportunity. Standards are said to encourage new forms of cooperation between producers and agribusinesses, to lead to the upgrading of supply chains and to facilitate access to new remunerative markets (Jaffee, 2003). Moreover, standards are also said to lead to better employment opportunities for rural households, to contribute to better working conditions on farms and to higher welfare for farm workers (Colen, Maertens \& Swinnen, 2012; Ehlert, Mithöfer \& Waibel, 2014). Seen from this viewpoint, the adoption of standards can lead to higher and more stable incomes and thereby to a reduction of poverty and vulnerability among rural households.

Public and private actors in the developing countries, often supported by development cooperation actors, have reacted to the increased demand for standards in several ways. Public actors have developed national or regional public standards that improve food safety and quality and are more inclusive than international private standards. Private actors, often in cooperation with the public sector, have developed their own national GAP standards that are benchmarked with the international standard GlobalGAP (e.g. ThaiGAP, ChinaGAP, KenyaGAP), but are more adapted to national conditions. More recently, supermarkets in developing countries have started to introduce private GAP standards to substitute for inadequate or missing public standards, to differentiate from produce sold by traditional retailers and to coordinate supply chains (Reardon, Henson \& Gulati, 2010).

\footnotetext{
${ }^{1}$ The standard is based on third-party certification, and farmers are audited by certification bodies accredited by Foodplus GmbH, the GLOBALGAP secretariat. GLOBALGAP is jointly governed by retailers and producers. In 2012, 49 retailers and food services were members of GLOBALGAP and 197 producers and suppliers. Of the latter, 32 came from developing countries (GLOBALGAP, 2012).
} 
Given the potential opportunities and challenges of food safety and quality standards, the aim of this chapter is to contribute to the understanding of how public and private actors in developing countries react to global and national standards and to analyse the implications of diverse standards on smallholders in the fruit and vegetable $(\mathrm{F} \& \mathrm{~V})$ value chain. To do this, we have carried out an extensive literature review. In addition, we have conducted semi-structured interviews with farmers, farmer organizations, extension workers, exporters and retailers in the Thai and Indian fruit and vegetable sector, as well as with government officials, researchers and food safety experts.

The proliferation of standards is at different stages in different developing countries. We analyse the evolution and proliferation of standards for the cases of Thailand and India. The two countries differ in several regards: the overall importance of private, international standards, the level of supermarket penetration and the level of engagement of the public and private sectors in standard development and dissemination.

The chapter proceeds as follows. First, we describe how Thailand and India address food safety and quality and how they have reacted to international standards, such as GlobalGAP, by introducing their own local public and private standards. We also discuss the importance of retailers in introducing standards in developing countries' domestic supply chains. Next, we review the literature on the impacts of standards on actors in the Thai and Indian F\&V value chain and compare findings among the two country cases. Last, we identify lessons learned from the comparison and provide policy recommendations.

\section{Public and Private Food Safety and Quality Standards in Thailand and India}

In this section, we look closer into how production and exports have evolved in both countries over the last decade, and into the diversity of food safety and quality standards. This focus is important. While Thailand and India are renowned as strong producers of agricultural commodities in Asia and worldwide, both countries are still plagued with severe food safety and quality problems. Issues of food safety and quality remain a real threat, particularly for exporters who try to respond to heightened global demand while simultaneously adapting to strict global quality standards. With the objective of easing the adaptation process, local governments have assisted producer-exporters by creating domestic standards. However, as the following discussion will show, this has not always been a success.

We begin by describing how production and export of fruits and vegetables have developed in both countries and explain how food safety and quality issues affect exports. We then go on to discuss the evolution of two broad categories of GAP standards that differ in terms of their levels of difficulty and coverage. These are: 
Table 1 Types and examples of GAP standards in developing countries

Level 1: Private GAP standards for the high-value export market

- Collective: GlobalGAP

- Chain-specific: Tesco Nature's Choice, Carrefour Quality Line

- National standards developed to achieve GlobalGAP benchmarking status (recognized as GlobalGAP equivalent): ThaiGAP, IndiaGAP and IndGAP

Level 2: Local GAP standards for the high-value domestic market and the export supply chain

- Standards owned by public actors (Q-GAP, revised IndiaGAP)

- Standards owned by private actors (ThaiGAP Level 2, basic IndGAP)

Source Hampel-Milagrosa and Holzapfel (2016)

Level 1 GAP standards for the high-value export market and Level 2 local GAP standards for the high-value domestic market and export supply chain (Table 1).

Level 1 GAP standards are private, third-party standards applied by lead firms in the food chain to meet consumers' concerns over food safety, to differentiate products based on quality attributes, to mitigate commercial risks and to ensure compliance with public regulations. Although voluntary, they are becoming increasingly mandatory to supply high-value markets worldwide. The most well-known Level 1 standard is the GlobalGAP standard, but there are also several chain-specific GAP standards with similar requirements (e.g. Tesco Nature's Choice). Moreover, both Thailand and India have developed national Level 1 standards (ThaiGAP and IndGAP) with the aim of being recognized as GlobalGAP equivalents. These are more adapted to local circumstances than the GlobalGAP standards, and therefore expected to be easier and less costly to comply with.

Level 2 standards are basic voluntary GAP standards that are introduced either by governments or by private actors or by both collectively as a public-private partnership. They are easier to comply with for smallholders than international standards (Level 1) and aim to fulfil two objectives: to ensure food safety in the domestic market and to gradually upgrade food safety systems to facilitate exports and to allow adoption of Level 1 standards (Amekawa, 2013; eFresh Portal, 2016; Korpraditskul, Suwannamook, Adulyarattanapan \& Damsiri, 2010). Basic GAP standards under Level 2 are diverse: some are not as stringent, whereas others are more challenging to comply with. In our case studies, both the public and private sectors in Thailand and India have introduced their own local Level 2 GAP standards for the high-value domestic markets and the export supply chain, resulting in two coexisting standards and confusion among producers and exporters.

\subsection{Production, Exports and Food Safety}

Thailand and India are among the largest producers and exporters of horticultural products in the world and among the developing countries most affected by increasing standards (Jaffee et al., 2005; Jairath \& Purohit, 2013; Manarungsan et al., 2005). In 
2014, India was the second largest producer of fruits (excluding melons) as well as of vegetables (including melons) (FAO, 2010). Thailand was the 14th largest producer of fruits (excluding melons) and the 41st largest producer of vegetables (including melons) (FAO, 2010). Despite high production volumes, Indian fruit and vegetable exports are relatively low. India is the 13th biggest exporter of vegetables (HS 07) and the 21st biggest exporter of fruits (HS 08) (ITC, 2017). One reason for low exports is that production is mainly targeted for domestic consumption. Another reason is producers' failure to adhere to international food safety and quality standards. Thailand, being the 11th biggest exporter of vegetables (HS 07) and the 20th biggest exporter of fruits (HS 08) (ITC, 2017), performs comparably better.

Both Thailand and India suffer from food safety issues which have negatively impacted exports to high-value markets, such as the European Union (EU). Unsafe farming practices are prevalent, resulting in high risks for the consumer and negative health impacts for farmers. Microbial contamination of fruits and vegetables is a problem as a result of poor hygiene practices, the use of untreated manure and polluted irrigation water (Shepard, 2006; UNIDO, NORAD \& IDS, 2015). Furthermore, pesticide overuse is common, especially among small-scale farmers, for whom pesticides provide an effective way to manage risks and are frequently applied as a preventive measure. Often, farmers follow a monthly or weekly spraying calendar and apply doses that are higher than what is recommended on the label (Plianbangchang, Jetiyanon \& Wittaya-Areekul, 2009; Shepard, 2006). This practice is encouraged by the fact that the physical appearance is the major factor for the determination of the market price in traditional supply chains (Shepard, 2006). For the case of Thailand, a recent study by Wanwimolruk, Phopin, Boonpangrak and Prachayasittikul (2016) showed that EU maximum residue limits (MRLs) were exceeded in 35-71\% of the cases, depending on the type of vegetable and the marketing outlet (local market or supermarket).

Thailand's fruit and vegetable exports to the EU fell steadily from 37,414 tons in 2007 to 23,187 tons in 2014 (ITC, 2017) (Table 2), ${ }^{2}$ which can partly be attributed to difficulties in meeting the increasingly strict standards in the EU. Within the group of middle-income countries, Thailand has the highest unit and percent rejection rates for exports of agrifood products into the EU and Japan (UNIDO et al., 2015). Thai imports account for $21 \%$ of all EU rejections due to pesticide residues (2002-2010), 21\% of Japanese rejections due to bacterial contamination (20062010) and $22 \%$ of Australian rejections on the basis of non-compliance with hygienic conditions/controls (UNIDO et al., 2015).

Similarly, India has also experienced high rejection rates for most of the agricultural commodities it exports. Based on aggregated 2002-2010 data from UNIDO et al. (2015), India ranked fourth among countries with the largest number of agrifood rejections from the EU, with a total of 1145 rejections or equivalent to $127 \mathrm{EU}$ rejections per year. Indian fruits and vegetables rank second to Mexico in terms of

\footnotetext{
${ }^{2}$ HS 0714 (manioc, arrowroot salem, etc.) is excluded from the analysis because almost the entire production of cassava in Thailand is processed into dry chips and pellets and then exported as animal feed (Ratanawaraha, Senanarong \& Suriyapan, 2001).
} 
Table 2 Production and export of fruits and vegetables in Thailand and India

\begin{tabular}{|c|c|c|c|c|c|c|}
\hline \multirow[t]{3}{*}{ Year } & \multicolumn{6}{|l|}{ Thailand } \\
\hline & \multicolumn{3}{|c|}{ Vegetables (tons) } & \multicolumn{3}{|l|}{ Fruits (tons) } \\
\hline & Production $^{\mathrm{a}}$ & $\begin{array}{l}\text { Exports to } \\
\text { world }^{\mathrm{b}}\end{array}$ & $\begin{array}{l}\text { Exports to } \\
\text { EU }^{\mathrm{b}}\end{array}$ & Production $^{\mathrm{c}}$ & $\begin{array}{l}\text { Exports to } \\
\text { world }^{\mathrm{d}}\end{array}$ & $\begin{array}{l}\text { Exports to } \\
\text { EU }^{\mathrm{d}}\end{array}$ \\
\hline 2007 & $2,74,7023$ & 239,281 & 23,591 & $12,622,969$ & 752,995 & 13,823 \\
\hline 2008 & $2,759,375$ & 250,795 & 22,437 & $10,993,626$ & 765,847 & 12,282 \\
\hline 2009 & $3,430,686$ & 251,327 & 19,036 & $10,798,782$ & $1,036,019$ & 13,505 \\
\hline 2010 & $3,623,646$ & 220,733 & 16,333 & $10,436,562$ & 913,390 & 11,800 \\
\hline 2011 & $3,833,422$ & 260,643 & 15,252 & $10,942,378$ & $1,222,597$ & 11,517 \\
\hline 2012 & $3,817,113$ & 238,359 & 13,001 & $11,081,410$ & $1,428,942$ & 15,056 \\
\hline 2013 & $3,903,385$ & 208,473 & 11,509 & $10,693,755$ & $1,431,090$ & 10,686 \\
\hline 2014 & $4,112,977$ & 201,548 & 12,593 & $11,341,667$ & $1,457,446$ & 10,594 \\
\hline \multirow[t]{3}{*}{ Year } & \multicolumn{6}{|l|}{ India } \\
\hline & \multicolumn{3}{|c|}{ Vegetables (tons) } & \multicolumn{3}{|l|}{ Fruits (tons) } \\
\hline & Production $^{\mathrm{a}}$ & $\begin{array}{l}\text { Exports to } \\
\text { world }^{\mathrm{e}}\end{array}$ & $\begin{array}{l}\text { Exports to } \\
\text { EU }\end{array}$ & Production $^{\mathrm{c}}$ & $\begin{array}{l}\text { Exports to } \\
\text { world }^{\mathrm{d}}\end{array}$ & $\begin{array}{l}\text { Exports to } \\
\text { EU }^{d}\end{array}$ \\
\hline 2007 & $88,532,008$ & $1,524,120$ & 106,756 & $63,888,880$ & 634,147 & 119,005 \\
\hline 2008 & $92,214,635$ & $2,262,600$ & 102,825 & $69,797,425$ & 827,372 & 153,539 \\
\hline 2009 & $91,441,005$ & $2,483,145$ & 91,034 & $70,242,281$ & 813,685 & 130,506 \\
\hline 2010 & $100,652,944$ & $1,716,045$ & 72,823 & $76,411,205$ & 386,012 & 121,800 \\
\hline 2011 & $107,050,691$ & $2,177,850$ & 152,743 & $75,241,396$ & 791,170 & 114,827 \\
\hline 2012 & $114,332,800$ & $2,347,190$ & 108,255 & $76,877,434$ & 837,762 & 121,132 \\
\hline 2013 & $120,992,200$ & $2,621,246$ & 120,320 & $84,004,249$ & 940,576 & 182,329 \\
\hline 2014 & $126,578,659$ & $2,533,913$ & 132,597 & $89,920,608$ & 805,033 & 144,994 \\
\hline
\end{tabular}

${ }^{a}$ Vegetables Primary (FAOSTAT)

${ }^{\mathrm{b}}$ HS 07 edible vegetables and certain roots and tubers, excluding HS 0714 roots and tubers (ICT) ${ }^{\mathrm{c}}$ Fruit including melons (FAOSTAT)

${ }^{\mathrm{d}} \mathrm{HS} 08$ edible fruit and nuts; peel of citrus fruits or melons (ICT)

${ }^{\mathrm{b}} \mathrm{HS} 07$ edible vegetables and certain roots and tubers

Sources FAO (2017), ITC (2017)

largest rejection rates for the US market, with a total of 8770 rejections or equivalent to 974 rejections per year (ibid). India joins Turkey, China and Vietnam in having the highest rate of rejections per US\$1 million of imports. UNIDO et al. (2015), and Roy and Thorat (2008) report that the most common grounds for rejection of Indian exports to EU are mycotoxins, food/feed additives and bacterial contamination. For produce directed to the American market, the most common reasons for rejection are wrong or inappropriate labelling, unhygienic conditions and bacterial contamination. Such high rates of rejection point to inadequate compliance, or lack thereof, to international standards (ibid). Indian fruit and vegetable exports to the EU, in contrast to Thailand, did not experience a decrease over the period from 2007 
to 2014 but increased by $23 \%$. However, the increase in exports is much lower than the increase in exports to world and production increases. Production increased by $42 \%$ and exports to the world by $55 \%$ over the same period (ITC, 2017).

\subsection{Level 1 Standards: Private GAP Standards for the High-Value Export Market}

There is considerable evidence that adopting Level 1 private food safety and quality standards such as GlobalGAP is especially challenging for small-scale farmers (Ashraf, Giné \& Karlan, 2009; Graffham et al., 2007; Roy \& Thorat, 2008). Compliance with standards entails high upfront investments in farm facilities and equipment, which smallholders are often not able to incur, especially if they lack access to credit (Jaffee et al., 2005). In addition, the costs of compliance with standards are, to a large extent, fixed costs, which disadvantage small-scale producers (Chemnitz, 2007; Jaffee et al., 2005). Besides, the technical and information requirements of standards are high. Farmers have to adopt more sophisticated farming practices, and they require producers to be informed about changing requirements of standards. However, acquiring information is also subject to economies of scale (Narrod et al., 2009; Roy \& Thorat, 2008). Poor education levels and a lack of access to extension services and training programmes further hinder the implementation of food safety and quality standards by small-scale farmers (Markelova, Meinzen-Dick, Hellin \& Dohrn, 2009).

In the light of the above-mentioned challenges, several donors, governments and NGOs in Thailand and India - as in other developing and emerging countrieshave initiated development programmes to facilitate the adoption of private standards by small-scale farmers (McCullough, Pingali \& Stamoulis, 2008). Most initiatives focused on the GlobalGAP standard, which became increasingly mandatory to supply the European market in the mid-2000s and therewith threatened to exclude small-scale farmers from high-value markets (Humphrey, 2008; Will, 2010). These programmes supported the creation of farmer groups and offered financial assistance, training and information to the groups to achieve certification (Humphrey, 2008; Kersting \& Wollni, 2012; Roy \& Thorat, 2008). Moreover, public-private partnerships were formed between donors and exporters to enable small-scale farmers to adopt the standard as part of exporter-outgrower schemes (Holzapfel \& Wollni, 2014a; Humphrey, 2008; Narrod et al., 2009; Roy \& Thorat, 2008).

Notwithstanding these developments, the number of GlobalGAP-certified producers remains low. In 2016, $188 \mathrm{~F} \& \mathrm{~V}$ producers in Thailand and $8006 \mathrm{~F} \& \mathrm{~V}$ producers in India were GlobalGAP-certified according to the GlobalGAP database. These are low numbers given that there are almost six million farms in Thailand and more than 263 million farms in India. In Thailand, the number of certified producers has even declined. While in 2009,809 producers in Thailand were certified with GlobalGAP, this number declined continuously until 2015 where only 55 producers were 
certified (Table 3). In 2016, the number of certified producers again slightly increased to 164 producers (GlobalGAP, 2016). According to Thai experts, the decline in the number of GlobalGAP-certified producers can be explained by a high number of Rapid Alert System for Food and Feed (RASFF) notifications. To avoid a ban by the EU on Thai exports of F\&V, the Thai government started in September 2010 to inspect $50 \%$ of produce intended for the European market. Earlier, only $10 \%$ of produce was randomly sampled. In addition, the government introduced an establishment list for exporters to the EU to increase the level of control. These measures have led to Thai F\&V exporters supplying the EU market to limit their production and activities.

A shift from group certification towards individual certification can be observed in the case of Thailand. Compared to individual certification, group certification can make compliance with GlobalGAP feasible for small-scale farmers by reducing the costs of compliance for the individual producers and by making it easier for external service providers to provide farmers with advice and training (Will, 2010). Two main group types exist under GlobalGAP option 2. The first is farmers' association or cooperative where the group is managed by farmers, and the second is an outgrower scheme of a company, where the company organizes smallholders and manages the group (GTZ, 2010). In Thailand, in 2009, only 29 producers were certified under option 1 while 780 farmers were certified in eleven farmer groups. In 2015, only two small producer groups with a total of 12 farmers were certified while the number of producers certified under option 1 increased to 43. This indicates that GlobalGAP adoption by smallholders is extremely challenging and often not sustainable as has also been shown by Holzapfel and Wollni (2014b). The case of India, however, shows that group certification can work. The number of farmers and groups certified in India has steadily increased from 2125 farmers (42 groups) in 2008 to 8006 farmers (87 groups) in 2016.

In addition to programmes supporting smallholders in adopting the GlobalGAP standard, both Thailand and India started developing their own national private standards, ThaiGAP, IndGAP and IndiaGAP, with the aim of achieving GlobalGAP benchmarking status, i.e. recognition as GlobalGAP equivalent. The standards are adapted to local circumstances and are thus expected to be easier and less costly to comply with than the GlobalGAP standard (Indian Agricultural and Processed Food Products Development Authority, 2011; Keeratipipatpong, 2010).

The ThaiGAP standard is a product of cooperation between the Thai Chamber of Commerce, Kasetsart University, the National Food Institute, the National Metrology Institute of Germany and the German Technical Cooperation Agency (Keeratipipatpong, 2010). The standard achieved benchmarking status in 2010 , but benchmarking was not renewed for GlobalGAP version 5 due to a low demand for the standard, which is reflected in the decreasing number of GlobalGAP-certified producers. It is not clear to what extent the ThaiGAP standard was successful in lowering costs of compliance and in making compliance less challenging.

The Indian case is rather complicated as there are two national standards with two different owners, namely: IndiaGAP owned by the Bureau of Indian Standards (BIS) and IndGAP owned by Quality Council of India (QCI). Both IndiaGAP and 


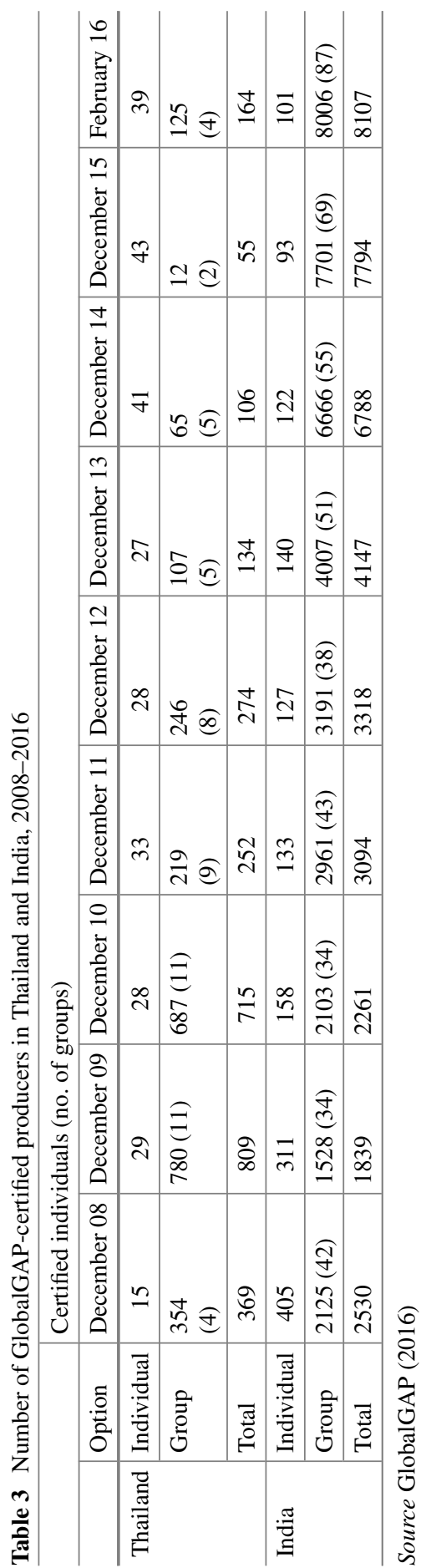


IndGAP still seek benchmarking against GlobalGAP (Punjabi \& Mukherjee, 2015; see www.qcin.org). The IndiaGAP, owned by BIS, was drafted by the Agriculture and Processed Food Export Development Authority (APEDA) in 2007 but was first officially released in 2010. Though a public standard, APEDA designed the IndiaGAP closely around the GlobalGAP but fitted to Indian conditions. IndiaGAP aims to help in the adoption of good agricultural practices all over the country and is oriented for Indian producers (both big and small farmers) that are in the high-value export market for agricultural products. Similar to the GlobalGAP, under the IndiaGAP certification scheme, farmers have two options for certification: individual and group certifications. It is expected that if IndiaGAP is properly implemented through certification of model farms, exports will increase by 25-30\% (Food Industry India, 2007; see also www.bis.org.in).

The IndGAP was drafted and released by QCI in 2014. According to a 2016 interview with a QCI representative, APEDA, after creating the draft IndiaGAP, turned over the draft documents to QCI to use as the basis for developing IndGAP. So, while APEDA was occupied promoting IndiaGAP, QCI developed IndGAP (national standard for high-value exports) and basic IndGAP (local standard for domestic market). Meanwhile, IndGAP originates from an institution created through privatepublic partnership (PPP), with up to 50\% funding from the government and the rest coming from industry bodies. QCI was set up as an accreditation body in India, and although its chairman is appointed by the Prime Minister, operationally, QCI is liberated from government control. QCI has a third-party verification system for the IndGAP in place.

IndiaGAP from APEDA and BIS is government-owned and government-led. Since its inception in 1980, BIS has been mandated by Parliament to prepare various Indian national standards and therefore had the legal authority to own and publish IndiaGAP. However, its implementation posed some problems. The structure of Indian government ministries is such that the Ministry of Agriculture is responsible for anything related to domestic agriculture whereas the Ministry of Commerce has the mandate for activities related to exports. Thus, since the original IndiaGAP refers to agricultural products that are destined to go outside of India, APEDA and BIS had to deal with two different Indian ministries whose jurisdictions overlap in the implementation of this certification scheme. A second issue is that unlike IndGAP, IndiaGAP does not allow for third-party verification. There is no third-party certification system that was built around IndiaGAP when the standard was drafted, creating problems of legitimacy and robustness of the standard. Thus, although efforts to have IndiaGAP benchmarked against GlobalGAP have been made, its lack of third-party verification needs to be resolved. 


\subsection{Level 2 Standards: Local GAP Standards for Broad-Scale Adoption}

Both the public and private sectors in Thailand and India have introduced local GAP standards for the high-value domestic markets and the export supply chain, resulting in two coexisting standards and confusion among producers and exporters.

\subsubsection{Thailand}

In Thailand, the government passed the 'Road Map of Food Safety' and introduced the Q-GAP standard, a national voluntary standard for good agricultural practices, in 2004. The aim was to implement effective food safety controls at all levels of the value chain (Ministry of Public Health, 2004; Sardsud, 2007a). The road map defines three goals: to maintain exports of agricultural commodities and food at the current level, to reduce quarantine problems and to reduce the number of illnesses from contaminated food in Thailand (FAO \& WHO, 2004).

Q-GAP initially consisted of 31 crop-specific protocols and was later extended to cover 169 commodities (Pongvinyoo, 2015; Sardsud, 2007a, p. 59). The Q-GAP scheme is implemented by the government at all stages. The government sets the standards, the National Bureau of Agricultural Commodity and Food Standards (ACFS) under the Ministry of Agriculture and Cooperatives (MOAC) serves as the accreditation body, and the Department of Agriculture (DOA) acts as a certification body. Since 2010, the certification and advisory function are partly outsourced to the private sector and to farmer organizations (Pongvinyoo, 2015). The Q-GAP is a requirement of several domestic retailers, and a requirement to export (Sardsud, 2007a; Wannamolee, 2008). In 2013, the Q-GAP standard was newly issued as Thai Agricultural Standard (TAS) of food crops and was harmonized with ASEAN GAP (Korpraditskul \& Ratanakreetakul, 2015), a standard developed by members of the Association of Southeast Asian Nations (ASEAN) to facilitate harmonization of GAP programmes among ASEAN member countries (ASEAN Secretariat, 2006). The private sector, however, assesses the Q-GAP standard as insufficient. ${ }^{3}$ To export to high-value markets, in particular Europe, the GlobalGAP standard is needed, which is challenging to adopt and entails high compliance costs for producers and exporters. Supermarkets operating in Thailand also assess the Q-GAP standard as insufficient.

Recognizing this, the Thai Chamber of Commerce, owner of the ThaiGAP standard, kicked off the development of ThaiGAP Level 2 for the domestic market. The ThaiGAP standard for the domestic market ensures a higher level of food safety than the Q-GAP standard, but is less challenging to comply with than the GlobalGAP/ThaiGAP standard (Wattanavaekin, 2010). It is seen as a tool for local

\footnotetext{
${ }^{3}$ The standard is criticized for lacking credibility because both certification and accreditation are in the hands of the government and the agencies responsible for certifying farmers lack adequate financing (Sardsud, 2007).
} 
producers to gain and maintain access to retailers and supermarkets in Thailand (Korpraditskul \& Ratanakreetakul, 2015). It is also used to promote the fruit and vegetable sector after the export crisis. The development of the ThaiGAP standard for the domestic market was supported by the Thai Retailers Association and several Thai supermarkets, among them Siam Makro, Tops Supermarket, Tesco Lotus and CP All Plc. Participating retailers aim to use ThaiGAP to ensure consumer safety and to differentiate their products. Thai consumers have been found to be sensitive to food safety and to shift from wet markets to supermarkets because they expect a higher level of food safety (Reardon et al., 2010; Reardon, Timmer \& Minten, 2012). The first producers became certified against the ThaiGAP standard for the domestic market in 2015.

\subsubsection{India}

Similarly, in India there are two parallel standards: the government-owned IndiaGAP — initiated by the BIS in cooperation with APEDA in 2010 — and the IndGAP standard, introduced in 2014 by a (semi-)private actor, QCI. Like ThaiGAP, both IndiaGAP and IndGAP have two levels: Level 1 for the high-value export market and Level 2 for the domestic market and to allow gradual upgrading to international standards. At Level 2, the revised IndiaGAP that was introduced in 2013 originated from BIS/APEDA while the basic IndGAP that was introduced in 2014 was developed by QCI (Punjabi \& Mukherjee, 2015; Jairath \& Purohit, 2013). The revised IndiaGAP was a simpler and less stringent certification scheme that would allow farmers to get used to domestic standards so that transition of crop production practices towards IndiaGAP and GlobalGAP accreditation would be easier. Both Level 2 local GAP standards were set up to address the fact that the GlobalGAP and IndiaGAP/IndGAP schemes that are currently in operation in India are meant only for the export market and are being operated by large farmers and farmer groups, overlooking the domestic market. Moreover, both schemes recognize the difficulties smallholders face in getting their produce accredited in order to enter high-value domestic markets. A Level 2 national accreditation is a small step that might eventually make Level 1 accreditation much easier for smaller farmers.

There has already been a certified model farm for IndGAP according to QCI. As of now, both the revised IndiaGAP and basic IndGAP are rather new and therefore no empirical evidence on their impact is available. However, our earlier research in India has shown that the majority of retailers, including international retailers, do not apply food safety and quality standards in India although they might apply them elsewhere (interview with IFPRI, 2014; Hampel-Milagrosa et al., 2017). Primary data from producers and retailers that were interviewed in the state of Andhra Pradesh show that modern retailers tend to implement basic product standards for fruits and vegetables but do not apply farm-level GAP standards. Supermarkets, for their fruits and vegetables portfolio, do not abide by public and private food safety standards (Cohen, 2013). Thus, modern Indian retailers' main criteria for selection of produce 
tend to neglect critical issues of food safety, including pre- and post-harvest practices, and workers' health and safety.

In addition, traditional markets still encompass a majority of the market share for fruits and vegetables in India, a contributing reason why standards are difficult to implement in the country (Babu, 2012; Gulati, 2007). Foreign direct investment (FDI) in retail is currently the key that allows modern retail chains to operate in the country, but actual investment is still very low (Baskaran, 2012). Many experts believe that once retail FDI enters on a bigger scale, stricter standards that conform to international criteria may be implemented and lead to improvements in the whole sector (interview with Global Agrisystems, 2014; Chari \& Madhav Raghavan, 2012).

\section{Implications and Impacts of Standards on Farmers}

This section summarizes the existing literature on the implications and impacts of standards on smallholders in Thailand and India. The analysis is carried out separately for Level 1 and Level 2 standards. In addition, we distinguish between Level 2 standards promoted by public actors and those demanded by domestic retailers since these were found to differ in their level of difficulty.

\subsection{Level 1 GAP Standards for High-Value Export Market}

Research on Level 1 standards focuses on the GlobalGAP standard. Findings from both countries on the factors influencing adoption, the impacts of adoption and the sustainability of certification show a similar pattern. Studies from India (Roy \& Thorat, 2008) and Thailand (Kersting \& Wollni, 2012) on the factors influencing GlobalGAP adoption find that if farmers are supported by external actors in the adoption process, such as a donor, an exporter or a marketing partner to a producer cooperative, it is not land size, but farmers' human and organizational capacities that are the main determinants of adoption. Small-scale farmers are unlikely to adopt the standard without support and need external assistance at all stages of the adoption process: to obtain the relevant information, to decide on whether or not to adopt the standard and to implement the requirements at farm level (Roy \& Thorat, 2008).

Studies show that once farmers have adopted the GlobalGAP standard, on an average, they gain from certification (Bourquin \& Thiagarajan, n.d.; Holzapfel \& Wollni, 2014a, 2014b; Punjabi \& Mukherjee, 2015; Roy \& Thorat, 2008). Using panel data of 218 farm households in Thailand, Holzapfel and Wollni (2014a, 2014b) find that GlobalGAP adoption, on an average, has a significant positive impact on $\mathrm{F} \& \mathrm{~V}$ prices as well as on farmers' household incomes. The impact on prices and household incomes depends highly on the type of institutional arrangement smallholders are certified in. Farmers certified in producer-managed groups had very high benefits and on average received 62\% higher prices and 14,678 USD higher net 
household incomes. In contrast, farmers certified in exporter-managed groups did not benefit from higher prices or incomes. Exporters covered expenses for certification and provided trainings, but farmers were not paid higher prices. Holzapfel and Wollni (2014b) also find that larger farmers in producer-managed certification groups realize high net income gains while smaller farmers only benefit as long as they do not have to incur the costs of compliance, i.e. as long as certification costs and costs for technical assistance, equipment and laboratory analyses are paid for by a donor.

For the case of India, Bourquin and Thiagarajan (n.d.) analysed the impact of a USAID-funded project supporting mango producers in India and found that GlobalGAP-certified farmers selling to the domestic high-value market receive 20$30 \%$ more and farmers selling to the export market 50\% higher returns than farmers selling through traditional channels. However, they also found that the additional revenue is not sufficient to pay for the costs of certification during the first year. Similarly, Punjabi and Mukherjee (2015) found that grape growers contracted by an exporter and producing under GlobalGAP have a $60 \%$ higher gross margin than farmers supplying to the traditional market. In addition, contracted farmers benefit from a lower price risk because of a minimum guaranteed price and from lower production risks. The export company's extension agents regularly inform farmers on weather and infestation risks and provide advice on the issues.

Small-scale farmers, however, need continuous support to make GlobalGAP certification sustainable. Holzapfel and Wollni (2014b), for the case of Thai F\&V producers, find that certification in donor-supported producer-managed groups is not sustainable. There are two main reasons for this. First, when donor support ends, small-scale farmers are often not able to cover the recurrent costs of compliance. Second, donor support focused on initial adoption and one-time certification and not on improving the long-term capacities of farmers and farmer groups to manage certification on their own. The results also showed that farmers certified in exportermanaged groups had a $85 \%$ higher probability of becoming re-certified (Holzapfel \& Wollni, 2014b). Exporters continued to support their contract farmers after donor support ended through extension services, input provision and management of the quality management system and by covering the certification costs.

A lack of sustainability of donor-supported GlobalGAP certification was also found in a USAID project supporting GlobalGAP certification of mango farmers in India. Only 26 out of 62 farmers who became certified in 2006 and 2007 sought recertification in 2008 (Bourquin \& Thiagarajan, n.d.). One of the lessons learned from the projects is that farmer groups that were not artificially formed for GlobalGAP certification but that had existed before (self-help groups, cooperatives, clusters) are more successful (Bourquin \& Thiagarajan, n.d.). Punjabi and Mukherjee (2015) also stress the importance of longer-term support to GlobalGAP-certified small-scale farmers. Record keeping about farm practices (e.g. pesticide and fertilizer use, and hygiene) is a particular problem for small-scale farmers. Extension agents of the contracting exporting company help farmers to maintain records for the first 2-3 years of certification until farmers acquire the capacity to fulfil the task themselves. 
The case of Mahagrapes (Roy \& Thorat, 2008), a marketing partner to producer cooperatives in India, shows a very successful example of collective action and farmer-led GlobalGAP certification. Mahagrapes provides a range of services to its member cooperatives and to farmers, such as procurement of information on standards and export markets, negotiation of contracts, provision of inputs, and training about grape growing and handling methods. It succeeded in providing GlobalGAP certification to all its member cooperatives. Member farmers only have to pay $\$ 28$ annually for certification due to economies of scale, which is much lower than has been found in other studies. The grape sector in India is a success story, and 6409 of the 8107 farmers in India currently certified against GlobalGAP are certified for grapes.

\subsection{Level 2 GAP Standards}

As shown above, Level 2 GAP standards for fresh fruits and vegetables exist in both Thailand (Q-GAP/TAS/ThaiGAP) and India (basic IndGAP/revised IndiaGAP). However, since basic IndGAP and the revised IndiaGAP have recently been introduced in India and only one farmer had been certified till 2015, the impacts on farmers are yet to be assessed. For this reason, this section focuses on the GAP standards in Thailand. The case of Thailand provides important lessons learned for India and other countries that have initiated basic voluntary GAP standards.

\subsubsection{Level 2 GAP Standards Promoted by Public Actors}

The TAS (previously Q-GAP) is widely known in Thailand. In 2016, 112 thousand farms in Thailand were certified against the standard (Department of Agriculture, 2016). This is almost as many producers as are certified with GlobalGAP worldwide (GLobalGAP, 2014), ${ }^{4}$ but a huge decline from more than 220,000 producers that were Q-GAP-certified in 2012 (Amekawa et al., 2017). The decline started with the introduction of the TAS in 2013 (TAS 9001-2013), which replaced Q-GAP and made it more challenging for Thai farmers to obtain a certificate. ${ }^{5,6}$ The revision of the Q-GAP standard is an attempt of the Thai government to improve the effectiveness of the standard and to increase its acceptance in international markets. Several studies

\footnotetext{
${ }^{4}$ According to GlobalGAP (2014), more than 139,000 certified producers in over 110 countries were certified in 2014.

${ }^{5}$ The TAS standard has 116 control pointsand farmers have to comply with $100 \%$ of 23 control points and with $60 \%$ of 41 control points. A total of 54 control points are recommendations (Amekawa et al., 2017). In comparison, the Q-GAP standard has only 84 control points and farmers were required to comply with only $51 \%$ of the control points (Amekawa, 2013).

${ }^{6}$ The GlobalGAP Integrated Farm Assurance standard Version 5 includes 218 control points, thereof 87 major must (100\% compliance), 113 minor must (95\% compliance) and 18 recommendations (GlobalGAP, 2015).
} 
have dealt with the impacts of the Q-GAP standard on food safety and farm practices and have analysed the benefits and problems associated with the standard.

Amekawa (2013), based on 64 structured interviews with Q-GAP-certified pomelo producers in Northern Thailand, analysed farmers' understanding of the Q-GAP standard and the effect of Q-GAP on farming practices and pesticide use. They find that only half the producers surveyed were able to relate the Q-GAP standard to the official food safety goal, the proper use and control of agrochemicals and other production practices. They also find that the level of implementation of Q-GAP requirements is low (especially record keeping) and that changes in pesticide management undertaken by farmers were unrelated to Q-GAP. Similarly, Schreinemachers et al. (2012), who compared pesticide use and handling practices among Q-GAP adopters and nonadopters, showed that a Q-GAP certificate does not have a significant effect on the amount of pesticides used nor on pesticide handling practices. It did, however, have a small impact on the use of hazardous and banned pesticide and has increased farmers' awareness of the dangers of hazardous substances.

The impact of Q-GAP on prices and income has been analysed by Krause, Lippe and Grote (2014) for cut orchids and by Pongvinyoo, Yamao and Hosono (2014) for coffee. Both find that Q-GAP does not influence prices and that certified and non-certified producers sell to the same buyers and markets. The lack of economic incentive for farmers to comply with Q-GAP requirements can be named as one of the reasons for farmers' non-compliance with Q-GAP requirements (Krause et al., 2014). More importantly, however, there are several problems associated with the design and implementation of the Q-GAP standard which lead to a low level of adoption of the standard requirements and ultimately to a lack of credibility.

First, accreditation and certification are both in the hands of the Ministry of Agriculture and Cooperatives, which creates doubts about the credibility of the certification system (Sardsud, 2007a). Second, overambitious targets to certify at least 145,000 farmers from 2004 to 2008 have put too much pressure on the responsible government agencies who lack capacities to carry out appropriate training, or inspection and certification services (Sardsud, 2007a). This has resulted in farmers applying for Q-GAP receiving insufficient training and in lax audit and control. For example, Schreinemachers et al. (2012) state that according to the DOA there are only 120 DOA auditors in Northern Thailand but more than 140,000 registered farms. The government has decided to outsource auditing to private contractors, but these are often only insufficiently trained. Third, auditing has focused mostly on final stages of production (pesticide residue testing and record keeping of pesticide applications) although the Q-GAP standard covers a much broader range of issues. Moreover, farmers are not sufficiently provided with alternatives to the use of synthetic pesticides, such as integrated pest management (IPM) methods (Schreinemachers et al., 2012).

Experiences from Thailand with the implementation of the Q-GAP standard provide important lessons for India. It is important that the APEDA and the QCI, which have launched IndiaGAP and IndGAP, ensure that farmers have access to sufficient information and training, that the quality of infrastructure is upgraded and 
that certification bodies have adequate capacities to carry out inspections. The development of a joint standard shared between APEDA and QCI is an option that we recommend. Not only will this joint standard unify the two seemingly competing public (IndiaGAP) and semi-private (IndGAP) standards but also reduce confusion among producers and among international buyers with regard to which standard has authority. Joining forces to create a joint standard will also increase capacities in terms of certification. There is always a trade-off between certifying as many farmers as possible and investing in training and auditing to ensure that farmers know and apply GAP principles and that certified farmers comply with the requirements of the standard.

\subsubsection{Private Level 2 GAP Standards Imposed by Domestic Retailers}

The impact of private standards applied by retailers in the domestic market is still very low in India but much stronger in Thailand where supermarkets have a much higher market share. With increasing market share of supermarkets and rising consumer concerns for food safety and quality, the impacts of standards are expected to increase significantly over the next decade.

As described in Sect. 2.3, supermarkets in India do not yet apply GAP standards. The situation in Thailand is different. Thai supermarkets use labels for fruits and vegetables, such as the Q-mark, pesticide-free or organic. In addition, supermarkets have introduced supply chain management programmes to ensure a basic level of food safety, developed their own food safety standards (e.g. Makro) or require certification with Q-GAP (e.g. Tops). This has certain implications for producers. For example, a case study of Tops carried out in 2006 showed that Tops, following a supply chain restructuring programme, significantly reduced its involvement with smallholders. Following a screening, Tops only chose those farmers as suppliers who already applied 'intelligent pesticide management' and started to require Q-GAP certification from suppliers (Buurma \& Saranak, 2006).

Fruits and vegetables are 2-6 times more expensive in supermarkets compared to local open-air markets (Wanwimolruk et al., 2016). Thai consumers are prepared to pay the price also because they expect produce to be safe. Wanwimolruk et al. (2016) in a recent study, however, found that fruits and vegetables from supermarkets exceed MRLs at a rate of $35 \%$ for Chinese kale (local markets $48 \%$ ), at a rate of $55 \%$ for pak choi (local markets $71 \%$ ) and at a rate of $49 \%$ for morning glory (local market 42\%). A similar study by the Thai Pesticide Alert Network (Thai-PAN) showed that produce labelled as Q-GAP-certified exceeded MRLs in 57\% of the cases and produce labelled as organic in $25 \%$ of the cases (Thailand PAN, 2016). These findings put high pressure on supermarkets as well as on ACFS which is responsible for the Q-GAP standard. Under these circumstances, the ThaiGAP standard for the domestic market, which is now piloted, may receive a boost.

There are not yet many experiences with the ThaiGAP standard for the domestic market, because the standard has only recently been introduced and uptil 2015, only 18 producers had received a certificate. Like GlobalGAP, the ThaiGAP (domestic 
Table 4 Comparison of the ThaiGAP standard for the domestic market with GlobalGAP

\begin{tabular}{l|l|l}
\hline \multicolumn{2}{l|}{$\begin{array}{l}\text { ThaiGAP domestic } \\
\begin{array}{l}\text { General regulation ruled by Thai chamber } \\
\text { of commerce }\end{array}\end{array}$} & ThaiGAP/GlobalGAP \\
\hline All farm base & 27 & 51 \\
\hline Crop base & 83 & 113 \\
\hline Fruit and vegetable & 57 & 70 \\
\hline \multicolumn{2}{l}{ Traceability (QR code) } & Traceability (QR code) \\
\hline Certification body of ISO 17065 & Certification of ISO 17065 GLOBALGAP \\
\hline
\end{tabular}

Source Korpraditskul and Ratanakreetakul (2015)

market) standard is a private, voluntary standard, but is adapted to the local circumstances and has a significantly lower number of control points (Table 4). The standard owner, the Thai Chamber of Commerce, has decided to offer only one certification option, individual certification for ThaiGAP (domestic market). The main reason provided by Thai Chamber of Commerce is that the experience of the GlobalGAP option 2 project has shown that the group certification process, especially the quality management system, is too complex.

It is yet to be seen whether ThaiGAP (domestic market) will also be an option for small-scale farmers. The 16 farmers that have already obtained a certificate have been proposed by the supermarkets involved in the ThaiGAP project. All of them are large-scale farmers that own between 8 and 32 hectares, which is much larger than the Thai average of 3.6 hectares (Pongsrihadulchai, 2009). However, some smallholders have been included in the certificates via contract farming arrangements.

Potentially, the ThaiGAP standard can play a big role in future in Thailand. Almost all major supermarkets in Thailand have supported the development of the standard which shows their high demand for safe fruits and vegetables. If applied at a broader scale and eventually made a requirement of Thai supermarkets, the standard is likely to improve the level of food safety for the domestic consumer and to decrease adverse environmental and health effects of pesticides. At the same time, there is the risk that small-scale farmers who are not able to comply will lose access to the lucrative supermarket channel. It is therefore important to identify ways to also enable smallscale farmers to adopt the standard.

\section{Conclusion and Recommendations}

Donor programmes on food safety and quality over the past decade have mainly focused on the GlobalGAP standard (Level 1 standard). The results of studies in Thailand and India show that even if access to donor support is available, it is the wealthier and more educated small-scale farmers who adopt and benefit from the GlobalGAP standard, indicating that the poorest segment of smallholders has not 
benefited from donor interventions. In addition, the vast majority of smallholders serve domestic markets or lower value export markets, where GlobalGAP is not a requirement.

Local Level 2 GAP standards applied in developing countries' domestic supply chains can potentially reach a much larger number of producers and as a result may have a much higher impact. On the one hand, if imposed by supermarkets, local standards may lead to changes in the supply chain. Although the standards applied to the domestic market are usually less stringent than GlobalGAP, they pose a similar threat and may lead to the loss of market access for resource-poor smallscale producers with limited human and social capital. On the other hand, they play an important role in introducing more sustainable agricultural practices and in improving the level of food safety for domestic consumers.

We found coexisting and overlapping local GAP standards (Level 2) initiated by public and private actors in both Thailand and India. In Thailand, the public sector has introduced the Q-GAP (now TAS) in 2004. The standard is a requirement for export, and the Q-GAP label is used by domestic supermarket chains. However, studies found that the level of implementation of standard requirements among certified farmers is low. The government lacks the resources and capacity to monitor compliance, and credibility is low because both certification and accreditation are in the hands of the government. As a result, the standard is assessed as insufficient by the private sector. Recognizing this, the private sector decided to develop its own local GAP standard, the ThaiGAP standard. ThaiGAP is a third-party standard based on GlobalGAP standard, but more adapted to local circumstances and with lower number of requirements. The four largest major supermarket chains in Thailand participated in the development of ThaiGAP, and if made a requirement, ThaiGAP may have major impact on the F\&V value chain.

In India, we found IndiaGAP (introduced by APEDA - a public institution) and IndGAP (introduced by QCI-a public/private institution) as two competing GAP standards geared for the same producers that are in the same high-value export market. Similar to Thailand, levels of implementation of standard requirements among farmers are low for both standards. However, whereas IndiaGAP was introduced much earlier with dismal certification rates among farmers, the IndGAP was only recently introduced and uptake could still increase. Also, similar to the case of Thailand, lack of resources hounds both institutions and the capacity to monitor compliance among farmers is low. The decision to introduce revised IndiaGAP (APEDA) and basic IndGAP (QCI) came in order to allow farmers to gradually ease into GlobalGAP standards. This was equally an opportunity to certify smaller farmers in India and provide assurance of food safety and quality to local consumers. Owing to the large numbers of smallholders in India, proper and widespread implementation of revised IndiaGAP and basic IndGAP is expected to have a profound impact on domestic markets.

Parallel standards - as found in both Thailand and India-lead to high transaction costs and uncertainty among producers, exporters and consumers. We therefore encourage public and private actors to harmonize existing GAP standards. Instead of aiming to certify as many smallholders as possible, governments are recommended 
to invest in upgrading the quality of the infrastructure needed for standard adoption (in particular, metrology and accreditation) and in extension programmes and media campaigns that disseminate GAP on a larger scale. The widespread awareness and application of GAP principles are particularly important to improve the level of food safety for domestic consumers.

Moreover, institutional arrangements that allow large numbers of small-scale farmers to adopt local GAP standards should be supported. Here, lessons can be learnt from the example of GlobalGAP, in which large-scale producers and enterprises support small-scale farmers in adopting standards. In addition, the support of service providers and producer cooperatives that offer access to financing and training to enable standard adoption by small-scale farmers is crucial. The grape sector in India is a particularly successful case, showing how large numbers of smallholders can be sustainably integrated into GlobalGAP group certification schemes and benefit from certification.

\section{References}

Amekawa, Y. (2013). Can a public GAP approach ensure safety and fairness? A comparative study of Q-GAP in Thailand. The Journal of Peasant Studies, 40(1), 189-217. https://doi.org/10.1080/ 03066150.2012 .746958$.

Amekawa, Y., Ng, C. C., Lumayag, L., Tan, G. H., Wong, C.S. et al. (2017). Producers' perceptions of public good agricultural practices and their pesticide use: The case of MyGAP for durian farming in Pahang, Malaysia. Asian Journal of Agriculture and Rural Development, 7(1), 1-16.

ASEAN Secretariat. (2006). Interpretive Guide for ASEAN GAP. Good agricultural practices for production of fresh fruit and vegetables in ASEAN countries. Food safety module. Retrieved from http://www.asean.org/storage/images/2012/publications/ASEAN\% 20GAP_Food\%20Safety\%20Module.pdf.

Ashraf, N., Giné, X., \& Karlan, D. (2009). Finding missing markets (and a disturbing epilogue): Evidence from an export crop adoption and marketing intervention in Kenya. American Journal of Agricultural Economics, 91(4), 973-990.

Babu, H. S. (2012). SWOT Analysis for opening of FDI in Indian Retailing. European Journal of Business and Management, 4(3).

Balsevich, F., Berdegué, J. A., Flores, L., Mainville, D., \& Reardon, T. (2003). Supermarkets and produce quality and safety standards in Latin America. American Journal of Agricultural Economics, 85(5), 1147-1154.

Baskaran, K. (2012). The FDI for multi brand retail trading in India-Green signal or red signal. Business Intelligence Journal, 15, 175-186.

Berdegué, J. A., Balsevich, F., Flores, L., \& Reardon, T. (2005). Central American supermarkets' private standards of quality and safety in procurement of fresh fruits and vegetables. Food Policy, 30(3), 254-269. https://doi.org/10.1016/j.foodpol.2005.05.003.

Bourquin, L. D., \& Thiagarajan, D. (n.d.). PFID: F\&V India Mango Market Development Project. Retrieved from: https://www.researchgate.net/publication/267834146_PFIDFV_India_Mango_ PFIDFV_India_Mango_Market_Development_Project_Market_Development_Project.

Buurma, J., \& Saranak, J. (2006). Supply-chain development for fresh fruits and vegetables in Thailand. In R. Ruben, M. Slingerland, \& H. Nijhoff (Eds.), Agro-food chains and networks for development. Den Haag: Springer.

Chari, A., \& Madhav Raghavan, T. C. A. (2012). Foreign direct investment in India's Retail Bazaar: Opportunities and challenges. The World Economy, 35(1), 75-90. 
Chemnitz, C. (2007). The Compliance Decision with Food Quality Standards on Primary Producer Level; A Case Study of the EUREPGAP Standard in the Moroccan Tomato Sector. 103rd EAAE Seminar 'Adding Value to the Agro-Food Supply Chain in the Future Euromediterranean Space', Barcelona, Spain. Retrieved from http://purl.umn.edu/9440.

Cohen, A. J. (2013). Supermarkets in India: Struggles over the Organization of Agricultural Markets and Food Supply Chains. University of Miami Law Review, 68(19-86).

Colen, L., Maertens, M., \& Swinnen, J. (2012). Private standards, trade and poverty: GlobalGAP and horticultural employment in senegal. The World Economy, 35(8), 1073-1088. https://doi.org/ 10.1111/j.1467-9701.2012.01463.x.

Department of Agriculture. (2016). Retrieved from http://gap.doa.go.th/.

Dolan, C. and Humphrey, J. (2000). Governance and Trade in Fresh Vegetables: The Impact of UK Supermarkets on the African Horticulture Industry. The Journal of Development Studies, 37(2), 147-176. https://doi.org/10.1080/713600072.

eFresh Portal. (2016). Good Agricultural Practices-Basic GAP for Small \& Marginal Farmers Retrieved from http://efreshglobal.com/eFresh/indgap_home.aspx.

Ehlert, C. R., Mithöfer, D., \& Waibel, H. (2014). Worker welfare on Kenyan export vegetable farms. Food Policy, 46, 66-73. https://doi.org/10.1016/j.foodpol.2014.01.004.

Elizabeth, M. M. Q. F., \& Reardon, T. (2000). Agrifood grades and standards in the extended Mercosur: Their role in the changing agrifood system. American Journal of Agricultural Economics, 82(5), 1170-1176.

FAO. (2010). FAOSTAT. Retrieved from http://faostat.fao.org/.

FAO. (2017). FAOSTAT. Retrieved from: http://www.fao.org/faostat/en/\#data/QC.

FAO, \& WHO. (2004). Strengthening official food safety control services. Paper prepared by Thailand. Paper presented at the Second FAO/WHO global forum of food safety regulators, Bangkok, Thailand, 12-14 October 2004. http://www.fao.org/tempref/docrep/fao/Meeting/008/y5871e/y58 71e02.pdf.

Food Industry India. (2007). India to notify standards for Agro products. Retrieved from: http:// www.foodindustryindia.com/newfood/detailnews.jsp?n=India $\% 20$ to $\% 20$ notify $\% 20$ standards $\%$ 20 for $\% 20$ agro $\% 20$ products\&id=214 website.

GLOBALGAP (2015). Control points and compliance criteria in IFA version 5 fruit and vegetables. Summary of Changes. Retrieved from Cologne: http://www.globalgap.org/export/sites/default/. content/.galleries/documents/150630_Summary_Changes_V5-0_CPCC_AF_CB_FV_en.pdf.

GLOBALGAP (2012). GLOBALG.A.P. website. Retrieved from: http://www.globalgap.org/uk_ en/for-producers/crops/FV/.

GLOBALGAP (2014). Building a global solution through partnership and collaboration. GLOBALG.A.P. annual report 2013-2014. Retrieved from Cologne.

Graffham, A., Cooper, J., Wainwright, H., \& MacGregor, J. (2007). Fresh Insights Number 15. Small-scale farmers who withdraw from GLOBALGAP: Results of a survey in Kenya. Retrieved from: http://r4d.dfid.gov.uk/PDF/Outputs/EcoDev/60506-Fresh-insights-15.pdf.

Gulati, A. (2007). Re-energizing Agricultural Sector of Andhra Pradesh: From Food Security to Income Opportunities IFPRI Discussion Paper Series. New Delhi: International Food Policy Research Institute (IFPRI).

Gulati, A., Minot, N., Delgado, C. L., \& Bora, S. (2007). Growth in high-value agriculture in Asia and the emergence of vertical links with farmers. In J. F. M. Swinnen (Ed.), Global supply chains, standards and the poor: How the globalization of food systems and standards affects rural development and poverty (pp. 91-108): CAB International.

Hampel-Milagrosa, A., Brannkamp, H., Cremer, T., Haddad, A., Pannwitz, K., Wehinger, F., et al. (2017). Retail FDI Liberalisation and the transformation of agrifood value chains in India. Bonn: German Development Institute/Deutsches Institut für Entwicklungspolitik.

Hampel-Milagrosa, A., \& Holzapfel, S. (2016). Diversity and implications of food safety and quality standards in Thailand and India. Bonn: German Development Institute/Deutsches Institut für Entwicklungspolitik. 
Henson, S., \& Caswell, J. (1999). Food safety regulation: an overview of contemporary issues. Food Policy, 24(6), 589-603. https://doi.org/10.1016/S0306-9192(99)00072-X.

Henson, S., \& Loader, R. (2001). Barriers to agricultural exports from developing countries: The role of sanitary and phytosanitary requirements. World Development, 29(1), 85-102. https://doi. org/10.1016/S0305-750X(00)00085-1.

Henson, S., \& Reardon, T. (2005). Private agri-food standards: Implications for food policy and the agri-food system. Food Policy, 30(3), 241-253. https://doi.org/10.1016/j.foodpol.2005.05.002.

Holzapfel, S., \& Wollni, M. (2014a). Innovative business models in the Thai horticultural sector: a panel data analysis of the impacts of global GAP certification. In R. D. Christy, C. A. D. Silva, N. Mhlanga, E. Mabaya, \& K. Tihanyi (Eds.), Innovative institutions, public policies and private strategies for agro-enterprise development Rome and Singapore: Food and Agriculture Organization of the United Nations; World Scientific Publishing Co. Pte. Ltd.

Holzapfel, S., \& Wollni, M. (2014b). Is GlobalGAP certification of small-scale farmers sustainable? Evidence from Thailand. Journal of Development Studies, 50(5), 731-747. https://doi.org/10. 1080/00220388.2013.874558.

Humphrey, J. (2008). Private standards, small farmers and donor policy: EUREPGAP in Kenya. Working paper series, 308. Retrieved from Brighton. https://opendocs.ids.ac.uk/opendocs/bitstr eam/handle/123456789/4167/Wp308.pdf?sequence=1\&isAllowed $=y$.

Humphrey, J., \& Memedovic, O. (2006). Global value chains in the agrifood sector.

Indian Agricultural and Processed Food Products Development Authority. (2011). Requirements for GAP - IndiaGAP (Draft Indian Standard), 18. Retrieved from: www.bis.org.in/sf/fad/FAD 22(2200)C.pdf website.

ITC. (2017). Trade map —international trade statistics. Retrieved from: http://www.trademap.org/ tradestat/Index.aspx.

Jaffee, S. (2003). From challenge to opportunity: Transforming Kenya's fresh vegetable trade in the context of emerging food safety and other standards in Europe. Agriculture and Rural Development discussion paper no.2 Retrieved from Washington, DC. http://documents.worldbank.org/curated/en/2003/12/5558962/challenge-opportunity-transf orming-kenyas-fresh-vegetable-trade-context-emerging-food-safety-other-standards-europe.

Jaffee, S., Henson, S., \& Rios, L. D. (2011). Making the grade: Smallholder farmers, emerging standards, and development assistance programs in Africa. A Research Program Synthesis. Washington DC: World Bank. Report(62324-AFR).

Jaffee, S., Meer, K. v. d., Henson, S., Haan, C. d., Sewadeh, M., Ignacio, L., ... Lisazo, M. B. (2005). Food Safety and Agricultural Health Standards: Challenges and Opportunities for Developing Country Exports. Retrieved from Washington, D.C.: http://siteresources.worldbank.org/INTRAN ETTRADE/Resources/Topics/Standards/standards_challenges_synthesisreport.pdf.

Jairath, M. S., \& Purohit, P. (2013). Food Safety and Regulatory Compliance in India: A Challenge to Enhance Agribusinesses. Indian Journal of Agricultural Economics, 68(July-September 2013), 430-448.

Keeratipipatpong, W. (2010). Thai farm product standard certified. Bangkok Post: ThaiGAP will help reduce trade barriers.

Kersting, S., \& Wollni, M. (2012). New institutional arrangements and standard adoption: evidence from small-scale fruit and vegetable farmers in Thailand. Food Policy, 37(4), 452-462.

Korpraditskul, R., \& Ratanakreetakul, C. (2015). THAI Good Agricultural Practice. Submitted for the FFTC-KU International Workshop on Risk Management on Agrochemicals through Novel Technologies for Food Safety in Asia, November 10-14, Sampran Riverside, Nakorn Pathom, Thailand. Retrieved from: http://ap.fftc.agnet.org/ap_db.php?id=558.

Korpraditskul, R., Suwannamook, S., Adulyarattanapan, S., \& Damsiri, W. (2010). Comparison study of GlobalGAP, IGAP and ASEANGAP. Retrieved from.

Krause, H., Lippe, R. S., \& Grote, U. (2014). Do Thai Cut Orchid Producers Benefit from Q-GAP Certification? Paper presented at the Tropentag 2014, Conference on International Research on Food Security, Natural Resource Management and Rural Development organised by the Czech 
University of Life Sciences Prague., September 17-19, 2014, Prague, Czech Republic. http:// www.tropentag.de/2014/abstracts/full/648.pdf.

Manarungsan, S., Naewbanij, J. O. \& Rerngjakrabhe. (2005). Costs of compliance with SPS standards: Thailand case studies of shrimp, fresh asparagus, and frozen green soybeans. Retrieved from Washington, DC.

Markelova, H., Meinzen-Dick, R., Hellin, J., \& Dohrn, S. (2009). Collective action for smallholder market access. Food Policy, 34(1), 1-7. https://doi.org/10.1016/j.foodpol.2008.10.001.

McCullough, E., Pingali, P. L., \& Stamoulis, K. G. (Eds.). (2008). The transformation of agri-food systems, globalization, supply chains and smallholder farmers. UK and USA: MPG Books Ltd, Bodmin.

Ministry of Public Health. (2004). Road map of food safety. Retrieved from Bangkok: http://www. fao.org/docrep/meeting/008/ae183e/ae183eApp.pdf.

Narrod, C., Roy, D., Okello, J., Avendaño, B., Rich, K., \& Thorat, A. (2009). Public-private partnerships and collective action in high value fruit and vegetable supply chains. Food Policy, 34(1), 8-15. https://doi.org/10.1016/j.foodpol.2008.10.005.

Otsuki, T., Wilson, J. S., \& Sewadeh, M. (2001). Saving two in a billion: quantifying the trade effect of European food safety standards on African exports. Food Policy, 26(5), 495-514. https://doi. org/10.1016/S0306-9192(01)00018-5.

Pingali, P. (2007). Westernization of Asian diets and the transformation of food systems: Implications for research and policy. Food Policy, 32(3), 281-298. https://doi.org/10.1016/j.foodpol. 2006.08.001.

Plianbangchang, P., Jetiyanon, K., \& Wittaya-Areekul, S. (2009). Pesticide use patterns among small-scale farmers: a case study from Phitsanulok, Thailand. Southeast Asian Journal of Tropical Medicine and Public Health, 40(2), 401.

Pongsrihadulchai, A. (2009). Use of farmers' registration for agricultural policy implementation in Thailand. Retrieved from Bangkok.

Pongvinyoo, P. (2015). Development of Good Agricultural Practices (GAP) in Thailand: A case study of Thai National GAP selected products. Retrieved from https://ir.lib.hiroshima-u.ac.jp/ files/public/38533/20151210144618141003/k6765_3.pdf.

Pongvinyoo, P., Yamao, M., \& Hosono, K. (2014). Factors affecting the implementation of good agricultural practices (GAP) among coffee farmers in Chumphon Province, Thailand. American Journal of Rural Development, 2(2), 34-39. https://doi.org/10.12691/ajrd-2-2-3.

Punjabi, M., \& Mukherjee, A. (2015). Grape exports under GLOBALGAP certification: the Mahindra and Mahindra initiative in India. Retrieved from http://www.fao.org/fileadmin/user_u pload/ivc/PDF/Asia/22_Punjabi_and_Mukherjee_Mahindra_GlobalGAP_grape_India.pdf.

Ratanawaraha, C., Senanarong, N., \& Suriyapan, P. (2001). Status of cassava in Thailand: Implications for future research and development. A review of cassava in Asia with country case studies on Thailand and Viet Nam. Rome: Food and Agriculture Organization of the United Nations.

Reardon, T., Henson, S., \& Gulati, A. (2010). Links between supermarkets and food prices, diet diversity and food safety in developing countries. In B. C. Hawkes C, Henson S, Drager N, Dubé L (Ed.), Trade, food, diet and health: perspectives and policy options (pp. 111-130). Hoboken, NJ: Wiley-Blackwell.

Reardon, T., \& Timmer, C. P. (2007). Chapter 55 Transformation of markets for agricultural output in developing countries since 1950: How has thinking changed? In R. Evenson \& P. Pingali (Eds.), Handbook of agricultural economics (Vol. 3, pp. 2807-2855): Elsevier.

Reardon, T., Timmer, C. P., \& Minten, B. (2012). Supermarket revolution in Asia and emerging development strategies to include small farmers. Proceedings of the National Academy of Sciences of the United States of America, 109(31), 12332-12337. https://doi.org/10.1073/pnas.100316 0108.

Roy, D., \& Thorat, A. (2008). Success in high value horticultural export markets for the small farmers: The case of Mahagrapes in India. World Development, 36(10), 1874-1890. https://doi. org/10.1016/j.worlddev.2007.09.009. 
Sardsud, V. (2007). National experiences: Thailand challenges and opportunities arising from private standards on food safety and environment for exporters of fresh fruit and vegetables in Asia: experiences of Malaysia, Thailand and Viet Nam (pp. 53-68). New York and Geneva: United Nations.

Schreinemachers, P., Schad, I., Tipraqsa, P., Williams, P. M., Neef, A., Riwthong, S., et al. (2012). Can public GAP standards reduce agricultural pesticide use? The case of fruit and vegetable farming in northern Thailand. Agriculture and Human Values, 29(4), 519-529. https://doi.org/ 10.1007/s10460-012-9378-6.

Shepard, A. W. (2006). Quality and safety in the traditional horticultural marketing chains of Asia. Retrieved from Rome.

Thailand Pesticide Alert Network. (2016). ผลการเฝ้าระวังารเคมีกาจัดศัตรูพืชตกค้างในผักและผลไม้ประจาปี 2559. Retrieved from http://www.thaipan.org/sites/default/files/file/pesticide_doc25_press_4_5_2559. pdf.

UNIDO, NORAD, \& IDS. (2015). Meeting standards, winning markets. Trade standards compliance. Retrieved from Vienna.

Wannamolee, W. (2008). Development of Good Agricultural Practices (GAP) for Fruit and Vegetables in Thailand. Retrieved from Bangkok: http://www.dld.go.th/organic/news52/audotor_3-5Ma r09/Aj.Wiboonwan/ThailandsGAP_report.doc.

Wanwimolruk, S., Phopin, K., Boonpangrak, S., \& Prachayasittikul, V. (2016). Food safety in Thailand 4: Comparison of pesticide residues found in three commonly consumed vegetables purchased from local markets and supermarkets in Thailand. PeerJ Preprints 4:e1928v1.

Wattanavaekin, W. (2010). Certification for international export markets Bangkok. Retrieved from Bankgkok.

Will, M. (2010). Integrating smallholders into global supply chains. GLOBALGAP option 2 smallholder group certification generic manual: lessons learnt in pilot projects in Kenya, Ghana, Thailand and Macedonia. Retrieved from Eschborn.

World Bank. (2008). Agriculture for development. World Development Report. Washington, D.C.: Author.

Open Access This chapter is licensed under the terms of the Creative Commons Attribution 4.0 International License (http://creativecommons.org/licenses/by/4.0/), which permits use, sharing, adaptation, distribution and reproduction in any medium or format, as long as you give appropriate credit to the original author(s) and the source, provide a link to the Creative Commons license and indicate if changes were made.

The images or other third party material in this chapter are included in the chapter's Creative Commons license, unless indicated otherwise in a credit line to the material. If material is not included in the chapter's Creative Commons license and your intended use is not permitted by statutory regulation or exceeds the permitted use, you will need to obtain permission directly from the copyright holder.

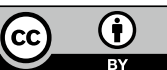

